\title{
EDIBLE UTENSILS IS CARING ABOUT THE ENVIRONMENT FUTURE OF THE PLANET
}

\author{
A. Robotko, A. Chorna, A. Shulga \\ National University of Food Technologies
}

\begin{tabular}{l}
\multicolumn{1}{c}{ Key words: } \\
Polymeric materials \\
Edible utensils \\
Classification \\
Technology \\
Biological decomposition \\
\hline \multicolumn{1}{c}{ Article history: } \\
Received 12.03.2019 \\
Received in revised form \\
02.04.2019 \\
Accepted 11.04 .2019
\end{tabular}

Corresponding author:

A. Robotko

E-mail:

npnuht@ukr.net

\begin{abstract}
Edible utensils made from food raw materials can be used with a drink or a dish. Creating edible utensils is not a new idea, but it is produced in small quantities at a high cost. In recent years, the idea of a safe and the edible plastic alternative has become a promising research area. The production of such utensils for food products is much more environmentally friendly than the existing polymer packaging because the raw materials for such utensils are organic natural ingredients, not plastic. And even if after using these utensils are thrown away, it will not stain the environment but will become a breeding ground for microorganisms. The European Commission has already approved a ban on the production of disposable utensils from polymeric materials. In Ukraine, it is also urging to reduce the use of plastic utensils.
\end{abstract}

The purpose of the research is to analyze the problem of the accumulation of polymeric materials and ways to solve it. The objects of research were selected from the most common types of edible utensils.

The article discusses the modern range and manufacturers of edible utensils. The main raw materials used for the manufacture of edible utensils have been analyzed. Promising raw materials for the manufacture of edible utensils are natural polymers of different origin: starch, agar-agar, casein, etc. The relevance and the prospect of replacing synthetic polymeric materials with biodegradable edible utensils are scientifically grounded. The composition of edible tableware and equipment for its production is characterized. Based on the analysis of literary sources, the classification of edible utensils is formed depending on the raw materials, the method of production, functional properties, size and purpose. Manufacturing techniques of edible dishes have been systematized, depending on the raw materials. The main requirements for the quality of edible utensils are considered.

DOI: $10.24263 / 2225-2924-2019-25-2-24$ 


\title{
ЇСТІВНИЙ ПОСУД - ПІКЛУВАННЯ ПРО ЕКОЛОГІЧНЕ МАЙБУТНЕ ПЛАНЕТИ
}

\author{
А.Ю. Роботько, А.І. Чорна, О.С. Шульга \\ Національний університет харчових технологій
}

Їстівний посуд, виготовлений з харчової сировини, можна вживати разом з напоєм або стравою. Створення їстівного посуду не нова ідея, але він виготовляється у невеликій кількості та має високу вартість. В останні роки саме ідея безпечної $i$, до того ж, їстівної альтернативи пластику є перспективним напрямом дослідження. Виробництво їстівного посуду для харчових продуктів більш екологічне, ніж існуюча полімерна упаковка, оскільки сировиною для такого посуду є органічні натуральні компоненти, а не пластик. I навіть якщо після вживання їжі ией посуд буде викинутий, він не забруднить навколишне середовище, а стане поживним середовищем для мікроорганізмів. Свропейська комісія вже схвалила заборону виробництва одноразового посуду з полімерних матеріалів. В Украйні також закликають зменшити користування пластиковим посудом.

Метою дослідження є аналіз проблеми накопичення полімерних матеріалів та шляхи ї̈ вирішення. Об'єктами дослідження обрано найрозповсюдженіші види їстівного посуду.

У статті розглянуто сучасний асортимент їстівного посуду. Проаналізовано основну сировину, що використовується для виготовлення їстівного посуду. Перспективною сировиною для виготовлення їстівного посуду є природні полімери різного походження: крохмаль, агар-агар, казеїн тощо. Науково обтрунтовано актуальність $і$ перспективу заміни синтетичних полімерних матеріалів на біорозкладний їстівний посуд. Охарактеризовано склад їстівного посуду й обладнання для його виготовлення. На основі аналізу літературних джерел сформовано класифікацію їстівного посуду залежно від сировини, способу виготовлення, функціональних властивостей, розміру та призначення. Систематизовано технології виготовлення їстівного посуду залежно від сировини. Розглянуто основні вимоги до якості їстівного посуду.

Ключові слова: полімерні матеріали, їстівний посуд, класифікація, технологія, біологічне розкладання.

Постановка проблеми. Їстівний посуд — це вироби, виготовлені з харчової сировини, які можна вживати разом $з$ напоєм або стравою. Розробленням такого посуду займаються провідні науковці розвинених країн світу, оскільки на сьогодні наша планета страждає від мільярдів тонн пластику (більше $80 \%$ усього сміття в світовому океані), який розкладається роками. Вчені встановили, що на нині на Землі знаходиться 6,3 млрд тонн пластикового сміття, кількість якого подвоїться до середини століття. Запропонована заміна - це шлях до зменшення екологічного навантаження на довкілля [1]. 
Європейська комісія схвалила заборону одноразових виробів з полімерних матеріалів, зокрема одноразового посуду, столових приладів, трубочок-соломинок для напоїв, ватних паличок і пластикових кріплень для повітряних кульок. Їх замінять на більш екологічно альтернативні варіанти, наприклад, паперові соломинки, водяні контейнери, чашки та ложки 3 печива. Використання одноразових пластикових пакетів і упаковок, які пропонують супермаркети, також планується істотно обмежити, що призведе до зниження викидів вуглекислого газу в атмосферу на 3,4 млн тонн. Крім того, пропозиції сприятимуть збереженню довкіллля, адже обсяг шкоди до 2030 року може скласти 22 млрд євро (за рахунок зменшення засмічених площ, витрат на фільтри) [2].

Використання їстівного посуду, на відміну від синтетичного, покращить екологічну ситуацію у світі, оскільки заміна $1 \%$ разового посуду збереже понад 2 млн м² лісових насаджень, дасть змогу уникнути забруднення понад 10 млрд м ${ }^{3}$ води, а найголовніше - зникне понад 10 млн кг сміття, яке потрібно переробляти.

Паралельно з розробленням і впровадженням їстівного посуду набуває популярності «природний бренд», оскільки замість наклеювання марки іiі тепер наносять лазером на шкірку фруктів та овочів, що немає шкідливого впливу на продукти. Компанії Rewe i Penny провели випробування лазерної техніки, призначеної для нанесення тексту і зображень безпосередньо на продукти (першими такими продуктами стали авокадо та батат). Прогнозують [3], що вже в 2020 році «біопластики» стануть конкурентоспроможною альтернативою нафтовим пластикам, які виробляються 3 органічних матеріалів (кукурудза, пшениця, цукрові буряки та навіть томати) та після утилізації стають добривом.

Метою статті $\epsilon$ аналіз проблеми накопичення полімерних матеріалів, встановлення доцільності заміни синтетичного разового посуду на їстівний, оскільки посуд 3 харчової сировини екологічний і простий у виробництві, та формування класифікації їстівного посуду.

Викладення основних результатів дослідження. Найбільш поширеною сировиною для виготовлення їстівного посуду є: водорості та речовини, отримані з них (агар) $[4,5]$, зернові культури (рис, пшениця, ячмінь, сорго) [6], грибковий міцелій [7], картопляний крохмаль [8], молочний протеїн (казеїн) [9] тощо. Відомі розроблені рецептури виготовлення столових наборів, починаючи з серветки і закінчуючи тарілкою для супу, з борошна, цукру, солі, яєць та молока [10-12].

На основі аналізу літературних даних ми розробили класифікацію їстівного посуду, яка наведена на рис. 1.

Одним 3 перших ініціаторів виробництва їстівного посуду є доктор Девід Едвардс з університету Гарварда (США). Він запропонував створити WikiCells (вікіклітини) - це тонка мембрана 3 натуральних продуктів, що містить рідини, емульсії, піни або тверді речовини. WikiCells має таку структуру: поверхневий шар (захисний), який складається 3 біологічно розкладального полімеру, за яким йде їстівна оболонка, всередині неї розміщується продукт. Аналог планується створити і для ресторанів та супермаркетів [13]. 


\section{ХАРЧОВІ ТЕХНОЛОГІЇ}

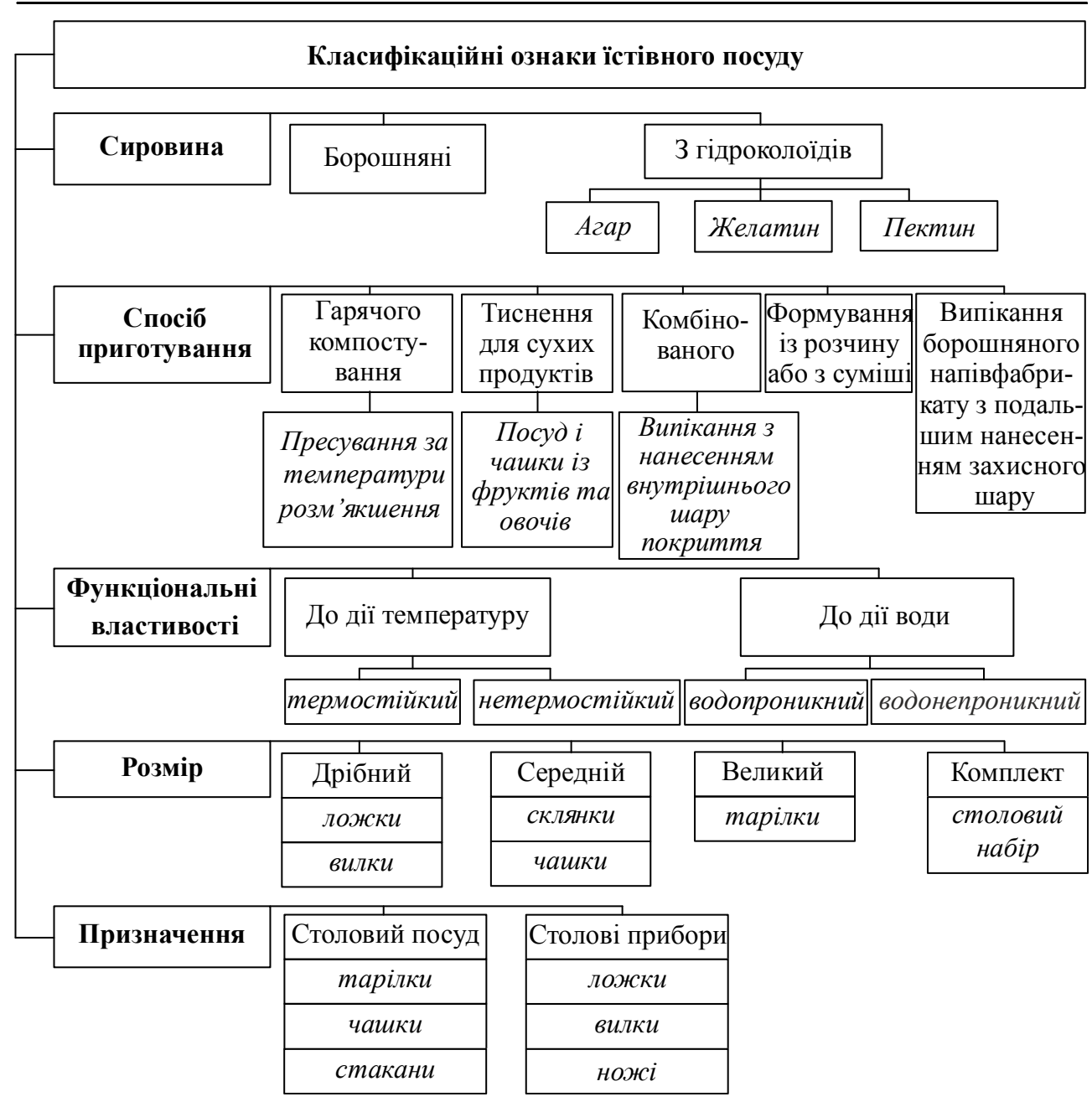

Рис. 1. Класифікація їстівного посуду

Ecovative Design (Нью-Йорк, США) - це компанія з виробництва екологічної упаковки з грибкового міцелію та матеріалів, що залишилися після збирання зерна (кукурудзяні стебла). Така упаковка безпечна та повністю розкладається через 90 діб [7].

Loliware (Нью-Йорк, США) — це перша одноразова їстівна термостабільна чашка, що гарантує безпечне вживання різноманітних напоїв, коктейлів і десертів, незалежно від температури. Скуштувавши напій, чашку можна з'їсти, в іншому випадку вона легко розкладається через 60 діб. Магазин Loliware пропонує декілька різновидів чашок, які є на 100\% біологічними. Основною сировиною для виробництва чашки є агар-агар, органічний тапіоковий сироп (отримують екстрагуванням маніоки), органічний цукор, вода та гарбузовий концентрат для кольору. Упаковка 39 чашок коштує 16 дол. США [5]. Lolistraw - це перша у світі їстівна, швидко компостувальна трубочка для 
напоїв на основі водоростей. У разі потрапляння в море розкладається без токсинів. Ціна за 10 трубочок складає 50 дол. США [5].

Мережа ресторанів Alfred Coffee \& Kitchen у Лос-Анджелесі (США) виготовляє стаканчики для кави з вафлі, краї якої вкриті молочним шоколадом, що нагадує ріжок для морозива, об'ємом $120 \mathrm{~cm}^{3}$. Вартість такої закуски до кави - 5 дол. США. Схожою ідеєю зацікавилася і мережа громадського харчування KFC. Стаканчик «Scoffee Cup», виготовлений зі спеціального печива, а всередині покритий шаром білого шоколаду з підвищеною термостійкістю. Зовні стаканчик покритий цукровим сиропом, який нанесений у вигляді логотипу компанії. Тож стаканчик абсолютно придатний для того, щоб налити в нього порцію кави. Шоколад підсолоджує напій і запобігає витіканню [10].

Дизайнер з Венесуели (Південна Америка) Enrique Luis Sardi у співпраці 3 італійською компанією Lavazza в 2003 році розробив екочашку для кави. Чашка зроблена $з$ тіста, вкритого спеціальною цукровою пудрою, яка є ізолятором і робить чашку водонепроникною. Печиво у вигляді ложки для кави достатньо щільне для того, щоб витримати розмішування гарячих напоїв. Ложки та чашки 3 печива продаються в наборі по 6 шт. [11].

Розроблено водяні пакети (контейнери) Ooho (Skipping Rocks Lab, Велика Британія), що виготовляються 3 морських водоростей для закуски. Такі пакети можуть бути ароматизованими та кольоровими. Вони є більш дешевими порівняно з полімерними та біологічно розкладаються через 4-6 тижнів [4].

Фірма Butt Foods (Велика Британія) пригощає клієнтів закладів ресторанного харчування гарячими стравами, які подаються в хлібі, випеченому в спеціальній духовій шафі. Хлібну тарілку можна розігріти в мікрохвильовій печі [10].

Компанія McDonald's з 2019 року почне впровадження паперових соломинок на заміну пластиковим, оскільки лише у Великій Британії на день використовується 1,8 млн соломинок. Це вплине на 3661 ресторанів McDonald's у Великій Британії, але не на решту 36000 ресторанів по всьому світу [14].

Do Eat (Бельгія) - це компанія, що випускає харчові продукти в їстівній упаковці, яка виготовляється з картопляного крохмалю та води. Упаковка не містить глютену, жирів, цукрів та інших добавок, які не підходять для вегетаріанців. Рекомендується зберігати продукти в контейнерах не більше двох годин. Їстівні контейнери необхідно запікати, смажити та нагрівати у мікрохвильовій печі, щоб досягти чіткої текстури продукту. Вони мають нейтральний аромат і тому можуть використовуватися як для солодких, так i для солоних страв, але не підходять для рідких. Їстівні контейнери можна зберігати 6 місяців. Вироби Do Eat швидко розкладаються й утилізуються в довкіллі як компост. Упаковка з 25 шт. обійдеться покупцям приблизно в 10 євро [8].

У Польщі існує повний столовий набір Bioterm - біологічно розкладний посуд, виготовлений з чистих пшеничних висівок, який виробляється в сучасному екологічному виробництві СС. Столові прибори виготовлені з суміші біорозкладальних пластмас і пшеничних висівок, мають низький вміст вугле- 
цю (від 1,3 до 1,6 г/кг), розкладаються в навколишньому середовищі через 30 діб. Пластини не згинаються, як папір або пластик, і стійкі до нагрівання в мікрохвильовій печі та духовці до $200^{\circ} \mathrm{C}$, також можуть бути заморожені. Гарячі страви в посуді можуть перебувати не довше 30 хв. Такі набори доступні у роздрібній упаковці по 10 шт. та по 100 шт. [6].

Дизайнер 3 Іспанії Андере Моньє урізноманітнив зовнішній вигляд i текстуру їстівного посуду за рахунок насіння різних рослин. Це зробило посуд більш привабливим на вигляд та дало змогу змінювати його текстуру i запах [10].

В Японії розроблено їстівний посуд з галет, які виготовлені з рисового борошна, солі та води для закладів громадського харчування [10].

У Словаччині подружжя українців у закладах ресторанного харчування подають корисні крем-супи у їстівних стаканчиках. Суп коштує від 2,30 до 3,10 євро. Усі супи - кремові, і споживаються без ложечки одразу із запечених стаканчиків. Використовується спеціальна піч, що випікає одразу два стаканчики за $3-5$ хв. Строк придатності такого супу - 3 год [12].

В Італії (м. Флоренція) до гарячих напоїв пропонується шоколадна ложка [15], а в Україні в ресторанах прийнято подавати український борщ у хлібі [16].

Учені з Німеччини розробили розчинні молочні контейнери на заміну пластмасовим контейнерам 3 вершками для кави. Контейнери $є$ двох смаків (солодкі та слабо підсолоджені), вони схожі на цукрові кубики, які наповнені питним або згущеним молоком. Поетапну схему формування молочних контейнерів наведено на рис. 2. Кристалічна плівка утворює таку упаковку навколо капсул, яка легко розчиняється в гарячій рідині. Сахароза і еритрит розглядаються як відповідні речовини для інкапсуляції питного і згущеного молока. Щодо процесу кристалізації, молочні капсули утворюються за рахунок кристалізації насиченого та згущеного молока. Для цього прес-форми наповнюють насиченим розчином молока (в якому міститься сахароза або підсолоджувач - еритрит, як альтернативна речовина для інкапсуляції). Спеціальне охолодження призводить до утворення твердих і стабільних кристалічних шарів [17].

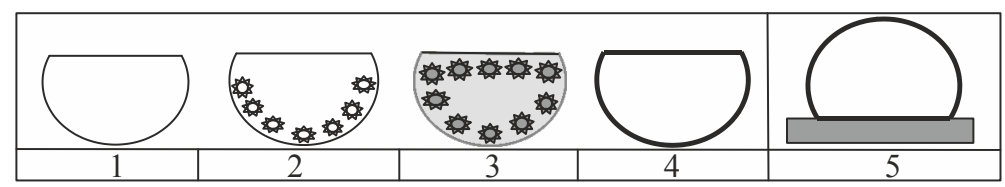

Рис. 2. Схема утворення молочних стручків: 1 - порожня форма; 2 - обсіяна форма; 3 - перенасичений розчин; 4 - охолоджене молоко; 5 - капсула, що містить молоко

Технологія виготовлення борошняного їстівного посуду передбачає певну послідовність етапів (рис. 3).

Сировиною може бути пшеничне або рисове борошно, яке в процесі оброблення формується та випікається. Пресування і сушка можуть стати способами обробки не тільки борошняних виробів, а й овочевих. 
Стакани для холодних напоїв, як правило, виготовляються з гідроколоїдів, що дає змогу отримувати прозорі вироби, які зовнішньо схожі на склянки. Технологія виготовлення таких виробів передбачає етапи, які наведено на рис. 4.

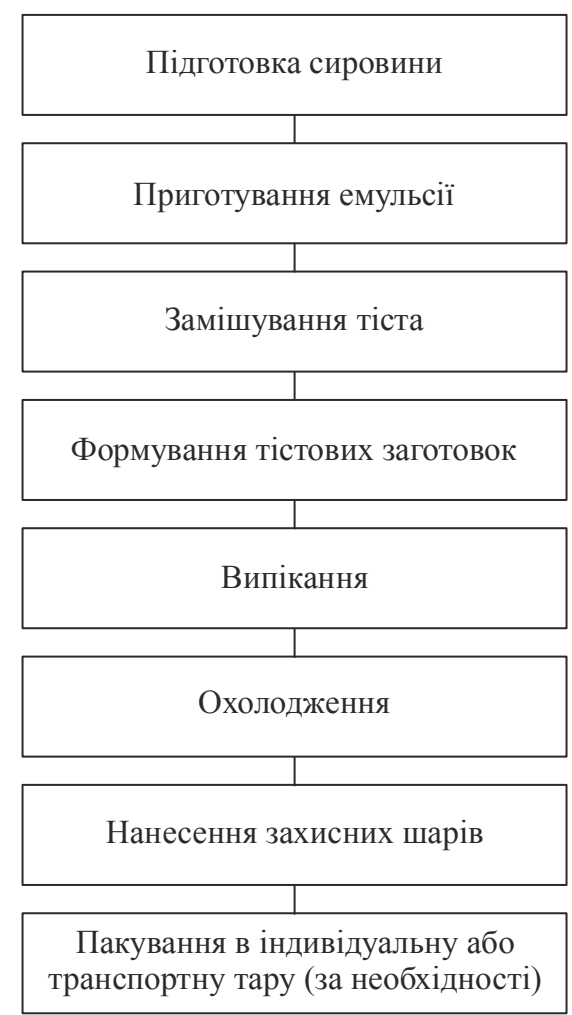

Рис. 3. Принципова схема виробництва борошняного їстівного посуду

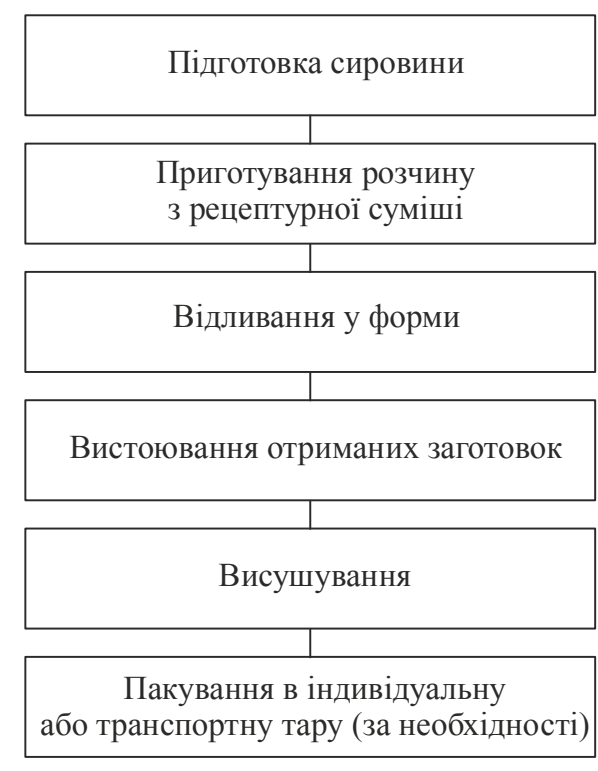

Рис. 4. Принципова технологічна схема виробництва їстівного посуду 3 гідроколоїдів

Складність активного впровадження їстівного посуду у виробництва та заклади масового харчування полягає в тому, що їх виготовлення передбачає використання спеціального обладнання, яке для більшості виробів необхідно виготовляти на замовлення, отже, потребує значних капіталовкладень. 3 метою скорочення кількості обладнання сушіння можна здійснювати в приміщенні виробничого цеху.

Більшість такого виду продукції виготовляється в місцях їх реалізації (кафе, ресторани, заклади громадського харчування). Підприємства, що працюють в інших країнах, мають ексклюзивне обладнання, де витримується потрібна температура та тиск, для виготовлення їстівного посуду. У разі виробництва в закладах громадського харчування з обладнання необхідно мати плиту, мікрохвильову піч (для перевірки на стійкість) та електропіч (для випікання тарілок, чашок). Для надання посуду певної форми потрібно закупити формувальний апарат або різноманітні формочки. Посуд певний час 
повинен бути стійким до вмісту в ньому рідини та нагрівання (в разі необхідності).

Якість виробленого посуду повинна відповідати основним вимогам: придатність до споживання; зручність у використанні; стійкість до певних температур і невеликим фізичним впливам (переміщення, натискання); вироби не повинні деформуватися в процесі транспортування [18-20].

\section{Висновки}

У результаті аналізу встановлено, що їстівний посуд є необхідною альтернативою заміни синтетичних полімерних матеріалів. Аналіз і узагальнення результатів опрацьованих літературних джерел дає змогу визначити перспективи подальшого дослідження та розроблення різновиду такого посуду. Перспективною сировиною для виготовлення їстівного посуду є крохмаль, желатин, агар-агар та інші гідроколоїди.

\section{Лiтература}

1. Laville Sandra, Taylor Matthew Nearly $1 \mathrm{~m}$ tonnes every year: supermarkets shamed for plastic packaging// The Guardian. URL: https://www.theguardian.com/environment/2018/jan/17/nearly-1m-tonnes-every-year-supermarkets-shamed-for-plastic-packaging (дата звернення: 15.10.2018).

2. Сврокомісія схвалила заборону одноразового пластикового посуду// Дзеркало тижня, Україна: інформ.-аналіт. URL: https://dt.ua/WORLD/yevrokomisiya-shvalila-zaboronu-odnorazovogo-plastikovogo-posudu-279032_html (дата звернення: 12.12.2018).

3. Guedim Zayan Bioplastics, Biopolymers from Agricultural Waste Will be Industry Standard by 2020// Edgy Lab. URL: https://edgylabs.com/bioplastics-biopolymers-agriculturalwaste-industry-standard-2020 (дата звернення: 12.12.2018).

4. Ooho! Water you can eat// Skipping Rocks Lab. URL: http://www.skippingrockslab.com/ooho!.html (дата звернення: 08.10.2018).

5. About LOLIWARE // Loliware . URL: https://www.loliware.com/pages/about-us (дата звернення: 08.10.2018).

6. Bioterm - Biodegradable Tableware// Ecolotec. URL: https://www.ecolotec.com/biotrem/index.html (дата звернення: 10.10.2018).

7. John N. Littering with Mushroom Packaging Helps the Environment// Edgy Lab. URL: https://edgylabs.com/littering-mushroom-packaging-helps-environment (дата звернення: 25.10.2018).

8. Do Eat - Packaging You Can Eat// Ecolotec. URL: https://www.ecolotec.com/doeat/home-use.html (дата звернення: 25.10.2018).

9. Horowitz Kate This Edible Packaging Is Made From Milk Protein// Mental Floss. URL: http://mentalfloss.com/article/84958/edible-packaging-made-milk-protein (дата звернення: 15.11.2018).

10. Їстівний посуд на шляху до поліпшення екологіï// «Екологічна варта». URL: https://agitbrigada-ekologichna-varta.webnode.com.ua/l/jistivna-posudna-shlyakhu-dopolipshennya-ekologiji/ (дата звернення: 16.11.2018).

11. Їстівний посуд — це сучасно // Екологія життя. URL: http://www.eco-live.com.ua/content/blogs/st-vnii-posud-tse-suchasno (дата звернення: 16.11.2018).

12. Середа Вікторія Суп смачний, а посуд ще смачніший// CBITUA. URL: http://m.svitua.com.ua/\#!/n/5134 (дата звернення: 25.11.2018).

13. Uys Emile The WikiCell: Nature-inspired edible packaging// Design Indaba. URL: http://www.designindaba.com/articles/creative-work/wikicell-nature-inspired-edible-packaging (дата звернення: 13.11.2018). 
14. Vaughan Adam McDonald's перейде на паперові соломинки до 2019 року // The Guardian. URL: https://www.theguardian.com/business/2018/jun/15/mcdonalds-to-switch-topaper-straws-in-uk-after-customer-concern (дата звернення: 13.11.2018).

15. Шоколад і кава Slitti// Slitti Cioccolato е Caffe. URL: http://www.slitti.it/ (дата звернення: 25.11.2018).

16. Яримко Олена Кращі ресторани української кухні: страви, що пахнуть Україною// IGO to World.com. URL: https://ua.igotoworld.com/ua/article/966_lu The Guardian вид. 17.01.2018chshie-restorany-ukrainskoy-kuhni.htm (дата звернення: 02.12.2018).

17. Wellner Martha, Ulrich Joachim Dissolving Milk Pods for Coffee // Wiley Online Library. URL: https://onlinelibrary.wiley.com/doi/full/10.1002/ceat.201600714 (дата звернення: 02.12.2018).

18. Виробництво і продаж їстівного посуду// Як заробити гроші. URL: http://jakzarobyty.pp.ua/5948-virobnictvo-prodazh-yistvnoyi-posudu-vs-deyi-dlya-zarobtku.html (дата звернення: 05.01.2018).

19. Як відкрити виробництво їстівної посуду? URL: http://toftrewitred.ru/stroyka/7399jak-vidkriti-virobnictvo-istivnoi-posudu.html (дата звернення: 05.01.2018).

20. Шульга О.С., Чорна А.I., Бойко M.I. Біодеградабельне їстівне покриття для створення екологічного посуду. Key issues of education and sciences: development prospects for Ukraine and Poland: International multidisciplinary conference, 20-21 July. Vol. 3. 2018. P. $100-103$. 